\title{
The Presence of Peptide Histidine-Isoleucine in Human, Dog, Guinea-Pig and Rat Pancreas
}

\author{
Y. Yiangou, N. D. Christofides, J. E. Evans and S. R. Bloom \\ Department of Medicine, Royal Postgraduate Medical School, London, UK
}

\begin{abstract}
Summary. Peptide histidine isoleucine-like immunoreactivity has been detected in the pancreas of man $(10.3 \pm 2.6 \mathrm{pmol} / \mathrm{g})$, $\operatorname{dog}(6.5 \pm 1.1 \mathrm{pmol} / \mathrm{g})$, guinea-pig $(5.8 \pm 0.9 \mathrm{pmol} / \mathrm{g})$ and rat $(0.7 \pm 0.1 \mathrm{pmol} / \mathrm{g})$ using a specific radioimmunoassay. Chromatographic analysis of the pancreatic extracts by high performance liquid chromatography indicated that both
\end{abstract}

guinea-pig and rat have a molecular form of the immunoreactivity which is distinct from the porcine intestinal peptide histidine-isoleucine.

Key words: Peptide histidine-isoleucine, radioimmunoassay, high performance liquid chromatography, pancreas.

\section{Introduction}

Recently a polypeptide with $\mathrm{N}$-terminal histidine and C-terminal isoleucine amide, and therefore called peptide histidine-isoleucine (PHI), has been isolated from porcine upper small intestine [1]. It has an amino acid sequence with a striking resemblance to vasoactive intestinal polypeptide (VIP) and has therefore been assigned to the glucagon-secretin family of peptides.

Subsequent studies have shown that PHI-like immunoreactivity, like that of VIP, is present throughout the gastrointestinal tract [2] and is also found in the brain $[3,4]$. In the human intestine PHI-like immunoreactivity has been localised exclusively in the nonendocrine cell layer (i. e. lamina propria and muscularis externa). This work suggests that any physiological role of PHI would most probably be as a neurotransmitter or a neuromodulator.

It has been reported that $\mathrm{PHI}$ is a potent stimulant of pancreatic juice secretion [5] and also potentiates insulin and arginine stimulated glucagon release from the isolated perfused rat pancreas [6]. The aim of our study was to determine whether PHI-like immunoreactivity is present in the pancreas of various species, and to characterise this immunoreactivity chromatographically.

\section{Materials and Methods}

\section{Extraction Procedure}

The pancreas of the following species were used for this study: - dog $(n=14)$, guinea-pig $(n=5)$, rat $(n=5)$ and $\operatorname{man}(n=5)$.
Rats and guinea-pigs were killed by cervical dislocation, dogs with an intraperitoneal injection of sodium pentobarbitone and the pancreas immediately dissected out. Specimens (approximately $1 \mathrm{~g}$ ) of human pancreas were collected at post mortem examination from five individuals and each gland was subsequently shown to be histologically normal. Two specimens were from the head, two from the tail, and one from the body of the pancreas. All pancreatic tissue was weighed and then rapidly placed in boiling $0.5 \mathrm{~mol} / 1$ acetic acid $(10 \mathrm{ml} / \mathrm{g})$ for $10 \mathrm{~min}$. After cooling, $50 \mu \mathrm{l}$ aliquots of the extract were measured in duplicate for PHI-immunoreactivity.

\section{Radioimmunoassay}

The radioimmunoassay is described in full elsewhere [2]. The antibody was raised by immunising lop-eared rabbits with pure natural porcine PHI (Karolinska Institute, Sweden) conjugated to bovine serum albumin (Miles Biochemicals, Slough, UK) with glutaraldehyde and was used at a final titre of $1 / 10,000$. The PHI tracer was prepared by the iodogen method [13] and purified by gel chromatography on a Sephadex G-50 superfine column. The assay was carried out in sodium acetate buffer $(0.1 \mathrm{~mol} / 1, \mathrm{pH} 4.0)$, containing $0.5 \%$ bovine serum albumin. 'Antibody-bound label' and 'free label' were separated by dextran-coated charcoal adsorption after 5-7 days incubation at $4{ }^{\circ} \mathrm{C}$. The inter-assay and intra-assay variations were $13 \%$ and $5 \%$ respectively. The assay showed no significant crossreactivity with other available peptides, in particular $<0.002 \%$ crossreactivity with VIP, glucagon, secretin, gastric inhibitory peptide (GIP), insulin, somatostatin, and pancreatic polypeptide. The assay could detect changes of $2 \mathrm{fmol} /$ tube with $95 \%$ confidence.

\section{High Performance Liquid Chromatography}

A Waters Associates (Milford, Massachusetts) high pressure liquid chromatographic system was used which included: - (1) M6000A and M45 pumps, (2) USK septumless injector, (3) M660 solvent programmer. The Bondapak $C_{18}$ column $(10 \mu \mathrm{m}, 3.6 \times 30 \mathrm{~mm})$ was obtained pre-packed from Waters Associates. Octadecylsilylsilica cartridges 
Table 1. Peptide Histidine-Isoleucine (PHI) in the pancreas

\begin{tabular}{lc}
\hline Species & $\begin{array}{l}\text { PHI immunoreactivity } \\
(\mathrm{pmol} / \mathrm{g})\end{array}$ \\
\hline Man & $10.3 \pm 2.6$ \\
Dog & $6.5 \pm 1.1$ \\
Guinea pig & $5.8 \pm 0.9$ \\
Rat & $0.7 \pm 0.1$ \\
\hline
\end{tabular}

Results expressed as mean \pm SEM
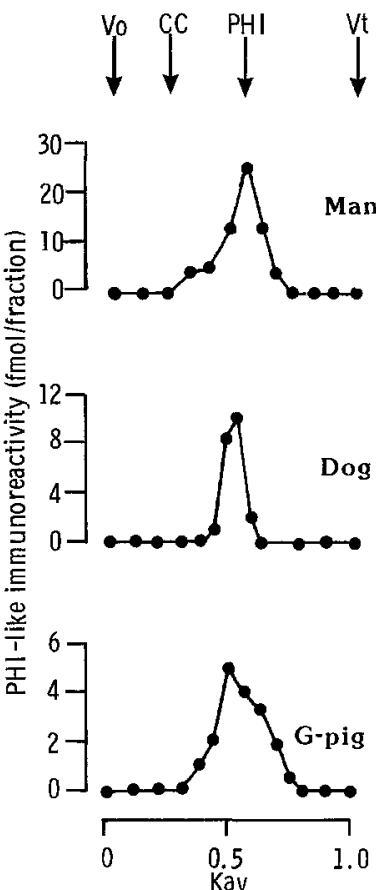

Fig. 1. Gel permeation chromatographic profiles of representative pancreatic extracts on a column $(0.9 \times 60 \mathrm{~cm})$ of Sephadex G-50 superfine. Vo - void volume; CC - horse heart cytochrome c; PHI peptide histidine-isoleucine; $V_{t}$ - bed volume. Concentrations are expressed as fmol/fraction. Kav is the elution coefficient [7]

(Sep-pak $\mathrm{C}_{18}$, Waters Associates) were activated by washing with acetonitrile (British Drug Houses, Poole, UK) followed by water. Pancreatic extracts, three from each species, of volumes $500-2000 \mu \mathrm{l}$ were applied. Weakly bound components were eluted with $20 \mathrm{ml}$ of water, and the 'hydrophobic' components were then eluted by $60 \%$ acetonitrile $(1 \mathrm{ml})$. The eluate was diluted with an equal volume of $0.12 \%$ trifluoroacetic acid (British Drug Houses, Poole, UK) and then injected into the system.

A combination of a linear gradient and isocratic elution was used. The gradient from $30 \%$ to $40 \%$ B (solvent A - $0.12 \%$ trifluoroacetic acid/water: solvent $\mathrm{B}-0.12 \%$ trifluoroacetic acid/acetonitrile) was run for $10 \mathrm{~min}$ and then kept at $40 \%$ B for a further $10 \mathrm{~min}$. The flow rate was $1 \mathrm{ml} / \mathrm{min}$ with $1 \mathrm{ml}$ fractions collected for subsequent radioimmunoassay.

\section{Gel Permeation Chromatography}

Tissue extracts were applied to a $0.9 \times 60 \mathrm{~cm}$ column (Pharmacia, Uppsala, Sweden) containing a $30 \mathrm{ml}$ bed volume of Sephadex G-50 superfine gel. Columns were run at a flow rate of $4 \mathrm{ml} / \mathrm{h}$ and were precalibrated with Dextran blue, horse heart cytochrome $\mathrm{c}, \mathrm{Na}^{125} \mathrm{I}$

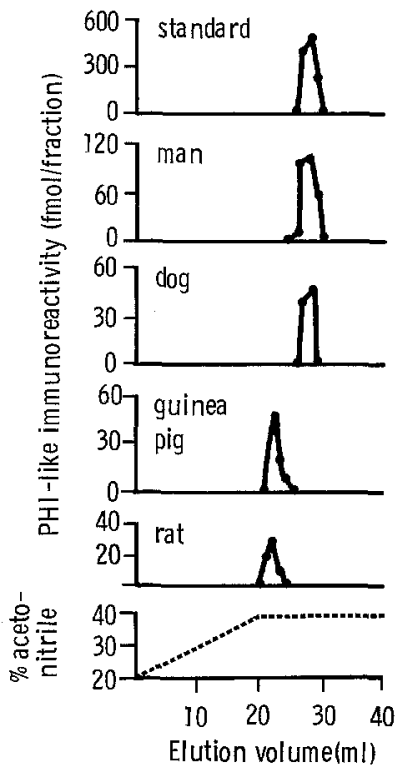

Fig. 2. Fractionation of pancreatic PHI-like immunoreactivity from four different species, on a reverse phase high performance liquid chromatography Bondapak C-18 column. Recoveries were $90 \pm 5 \%$. The bottom panel shows the acetonitrile gradient. Pure natural PHI standard, human and dog pancreatic PHI immunoreactivities were eluted at $28 \mathrm{ml}$, while those of rat and guinea-pig were eluted at $22 \mathrm{ml}$

and porcine PHI standard. Dextran blue, cytochrome c and a trace amount of ${ }^{125} \mathrm{I}$ were added to each sample as internal markers. The columns were eluted with $0.1 \mathrm{~mol} / 1$ sodium acetate buffer $(\mathrm{pH} 4.0)$ containing $2 \%$ bovine serum albumin. Aliquots $(50-200 \mu \mathrm{l})$ of the eluted fractions $(1 \mathrm{ml})$ were then assayed for their PHI content. An estimation of the column recovery was achieved by assaying the neat extract.

\section{Calculations}

Concentrations of PHI-like immunoreactivity are expressed in $\mathrm{pmol} / \mathrm{g}$ wet weight of tissue and quoted as the mean \pm SEM. For the direct comparison of the elution profile in each gel chromatographic run, the elution coefficient (Kav) was calculated according to Laurent and Killander [7].

\section{Results}

Table 1 shows the concentrations of immunoreactive PHI in the pancreas of the species studied. The concentrations were lowest in the rat and highest in the human pancreas. Representative gel chromatographic profiles for PHI immunoreactivity in three species are shown in Figure 1. In each case (except for the dog) in which the peak was narrower the PHI immunoreactivies emerged as broad peaks with recoveries ranging from $73 \%$ to $102 \%$. Figure 2 shows the fractionation of tissue extracts by reverse phase high performance liquid chromatography, on which both the rat and guinea-pig immunoreactivities eluted earlier than that of the other species studied, which were co-eluted with the porcine PHI standard. 


\section{Discussion}

The results presented here suggest that $\mathrm{PHI}$, a recently isolated putative neurotransmitter, is present in the pancreas of several mammalian species. Chromatographic characterisation on Sephadex G-50 of the pancreatic immunoreactivity suggested that the material from all the species studied included material of the same molecular size as the porcine PHI standard. However, the use of reverse phase high performance liquid chromatography revealed significant species differences. Both guinea-pig and rat PHI immunoreactivities appeared to be less hydrophobic than the porcine PHI standard and were thus eluted significantly earlier. Human and dog PHI immunoreactivities were co-eluted with the porcine PHI standard. The finding of very low apparent concentrations of PHI immunoreactivity in the rat pancreas may thus be due to a lower cross-reactivity of rat PHI with the antibody used in this study.

Recently it has been found that PHI immunoreactivity is not confined to the upper small intestine but is distributed widely throughout the body. Highest levels of PHI immunoreactivity occur in the ileum and colon [9], but significant amounts (similar concentrations to those found in the pancreas) were also found in the brain and respiratory tract [8]. The concentration of PHI immunoreactivity in the pancreas is of a similar magnitude to those of the other putative neurotransmitters, bombesin [12] and VIP [11], but several orders of magnitude lower than the pancreatic hormones, glucagon, insulin and pancreatic polypeptide [10]. The concentration of peptides of widely different functions cannot, of course, be equated with their physiological importance.

Our finding that PHI immunoreactivity is found in the pancreas suggests that reports of the action of PHI on exocrine and endocrine pancreatic secretion may be physiologically relevant.

Acknowledgements. This study was supported in part by grants from the British Diabetic Association and Novo Company Ltd.

\section{References}

1. Tatemoto K, Mutt V (1981) Isolation and characterisation of the intestinal peptide PHI (PHI-27), a new member of the glucagonsecretin family. Proc Natl Acad Sci USA 78: 6603-6607
2. Christofides ND, Yiangou Y, Aarrons E, Ferri GL, Tatemoto K, Polak JM, Bloom SR (1983) Radioimmunoassay and intramural distribution of PHI-IR in the human intestine. Dig Dis Sci 28: $507-512$

3. Christofides ND, Yiangou Y, McGregor GP, Aarons E, Woodhams PL, Tatemoto K, Bloom SR (1982) Distribution of PHI in the rat brain. Biomed Res 3: 573-574

4. Christofides ND, McGregor GP, Woodhams L, Yiangou $\mathrm{Y}$, Aarons E, Tatemoto K, Bloom SR (1983) Ontogeny of PHI in the rat brain. Brain Res 264: 359-361

5. Dimaline R, Dockray GJ (1980) Actions of a new peptide from porcine intestine on pancreatic secretion in the rat and turkey. Life Sci 27: 1947-1951

6. Szecowka J, Tatemoto K, Mutt V, Efendic S (1980) Interaction of a newly isolated intestinal peptide (PHI) with glucose and arginine to effect the secretion of insulin and glucagon. Life Sci 26: $435-438$

7. Laurent TC, Killander J (1964) A theory of gel filtration and its experimental verification. J Chromatog 14: 317-330

8. Christofides ND, Yiangou Y, Piper PJ, Ghatei MA, Tatemoto K, Polak JM, Bloom SR (1982) Distribution of PHI in the mammalian respiratory tract and some aspects of its pharmacology. Regul Pept 4: 359 (Abstract)

9. Christofides ND, Yiangou Y, McGregor GP, Ghatei MA, Tatemoto K, Polak JM, Bloom SR (1982) Dual localisation of PHI in the gut and brain. Gut 23: A883 (Abstract)

10. Gersell DJ, Gingerich RL, Greider MH (1979) Regional distribution of pancreatic polypeptide in the human and canine pancreas. Diabetes 28: 11-15

11. Bishop AE, Polak JM, Green IC, Bryant MG, Bloom SR (1980) The location of VIP in the pancreas of man and rats. Diabetologia 18: $73-78$

12. Ghatei MA, Jung RH, Stevenson JC, Hillyard CJ, Adrian TE, Lee YC, Christofides ND, Sarson DL, Mashiter K, MacIntyre I, Bloom SR (1982) Bombesin: Action on gut hormones and calcium in man. J Clin Endocrinol Metab 54:980-985

13. Fraker PJ, Speck JC (1978) Protein and cell membrane iodinations with a sparingly soluble chloramide $1,3,4,6$-tetrachloro- $3 a$, 6adiphenylglycoluril. Biochem Biophys Res Comm 80: 849-857

Received: 14 October 1982

and in revised form: 20 May 1983

Professor S. R. Bloom

2nd Floor Francis Fraser Laboratories

Hammersmith Hospital

Du Cane Road

London W12 OHS, UK 